\title{
ECONOMIC CRITERIA CHARACTERISING BANK SOUNDNESS AND STABILITY
}

\author{
Askoldas Podviezko ${ }^{1}$, Romualdas Ginevičius ${ }^{2}$ \\ Vilnius Gediminas Technical University, Sauletekio ave. 11, LT-10223 Vilnius, Lithuania \\ E-mail: ${ }^{1}$ askoldas@lycos.com, ${ }^{2}$ romualdas.ginevicius@vgtu
}

\begin{abstract}
There are many different analysis methods for evaluation of complicated socio-economic processes. Banks are important participants of the market. Soundness and stability of banks is difficult to assess because of their complicated internal business structure, intertwined cash flows and strong influence of market conditions on bank's performance. Multi-criteria methods of evaluation are among major methods being used nowadays for evaluation of complex socio-economic processes. A base for using such methods serves criteria representing these processes. Their relative importance is assigned by attributing proper weights to these criteria. Choice of criteria is essential part of analysis of soundness and stability of banks.
\end{abstract}

Keywords: bank evaluation, multi-criteria methods, bank rating, criteria weights.

\section{Introduction}

The recent financial crisis has induced many discussions about stability of financial system, which is naturally dependent primarily on banks. Bank stability issue became crucial for both depositors and governments of different countries. In the USA 202 banks became bankrupt during 20002010 (FDIC 2010a). Very unfortunately, this affected solvency of the FDIC fund thus reducing the reserve ratio from around $1.2 \%$ of the total of insured deposits in the period from June, 2005 to December, 2007 to $0.014 \%$ in June 2009 (Shedlock 2009). Accounts of individuals and firms are FDIC insured for aggregate balances not exceeding 250000 USD until 31 December 2013 (on 1 January, 2014 the standard insurance amount will return to its standard amount 100000 USD per depositor) (FDIC 2010b). Such government insurance to high extent mitigates the risk of depositors, unlike large enterprises' monies. From government perspective, though problematic banks induce large budget burdens of payouts to depositors.

In spite of the fact that in the Republic of Lithuania deposits of individuals and firms are insured for the aggregate amount of deposits up to 100000 EUR equivalent per depositor, as states Deposit Insurance (Indèliu draudimas 2010), the insurance coverage is provided in LTL though (local Lithuanian currency), thus making the bank stability issue important for depositors who made deposits in foreign currencies as devaluation of LTL is recently being an important issue of public discussions. The relative part of deposits in foreign currencies made by depositors in Lithuania especially individual ones has a strong tendency to increase (The Bank of Lithuania 2009). State deposit insurance has other shortcomings. Decreasing credit ratings of Lithuania can negatively affect attractiveness of the insurance scheme. Other shortcoming is insufficient insurance amount for enterprises and potential real estate buyers, a lot of which are present in the market: $70 \%$ of households would attempt to improve their living conditions if they could save enough money (Jonaitis et al. 2003). By the other hand, from the macro economic perspective bank stability issue is vital in ensuring stable functioning of economics. It is clear that the problem of evaluation of bank stability is of both practical and theoretical interest.

Naturally, this paper raises discussion about the necessity of evaluation of banks from the depositor's perspective and sets the goal of evaluation of local banks from this perspective. A difference between our goals and common prevailing approaches of evaluation of banks from the perspective of investors is shown. The main goal of this paper is to propose a methodology for evaluation of banks in the local market for the purpose of serving depositors with the outcome of outranking result exposing reliability and soundness of local banks. Below in this paper it is shown that evaluation of banks from the depositor's perspective is based on different approaches and has a different span than in prevailing approaches created to serve investors. A quantitative multi-criteria approach is proposed for such evaluation and various possible criteria for these methods.

\section{Bank evaluation industry at present}

Bank valuation spans a long history. Standard and Poor's Rating Services has launched their business of evaluation in 1860; Moody's Investors Service Inc. in 1909. Later other firms followed: Fitch Rat- 
ings Ltd., established in 1913; A.M. Best Company; DBRS Ltd. (Dominikon Bond Rating Service); Japan Credit Rating Agency, Ltd.; Rating and Investment Information, Inc.; CBRS (Canadian Bond Rating Service); Duff (Duff and Phelps Credit Rating Service); JBRI (Japanese Bond Rating Institute); NIS (Nippon Investor Service); Thompson Bank Watch (absorbed by Fitch Ratings Ltd. in 2000), etc. The seven first rating agencies in the list above have been registered with the US Securities and Exchange Commission as nationally recognized statistical rating organizations ("NRSRO") in 2007.

Other types of ratings of commercial banks could be found as well. Top 500 Banking Brands listing was recently published by the magazine "The Banker" (2009). Awards named like „The Bank of the Year" are continuously being granted by Euromoney, "The Banker", "Global Finance", etc.

Mentioned rating agencies carry out substantial amount of work with a certain bank, discussing a list of questions, also by presenting questionnaires to management of an evaluated bank. For example, the questionnaire framework of Fitch Ratings Ltd. comprises questions about market environment and planning, ownership, audit/control by national banking supervisory auditory and accounts, corporate governance, performance/earnings, risk management, lending, contingent risks, credit derivatives, securitisation, market risk, operational risk, funding and liquidity, capital, loan loss and risk reserves. In spite of the large scope of probing and the fact that bank evaluation has a long history and tradition starting from the end of the $18^{\text {th }}$ century, evaluation by a rating agency would have the same shortcoming: it is usually based on opinion of a limited number of experts employees of the firm (Le Bras, Andrews 2004; Foley 2007), which could make such evaluation biased due to high subjectivity involved. It is rather clear that an evaluating agency cannot employ a sufficiently large number of employees to reduce subjectivity issue due to a very high salary expenditure burden thus would be incurred.

\section{Methodology for bank evaluation from the depositor's perspective}

Other approach discussed in this paper is based on multi-criteria methods, which make it possible to outline a uniform framework for evaluation of all banks present in the market simultaneously (Figueira et al. 2005; Ginevičius, Podvezko 2004, 2008b, 2008c; Podvezko 2006, 2008). The process comprises few stages. First and probably the most difficult task is making choice of criteria among a vast number possible. Bank business is complicated and thus comprises different separate activities, intertwined between each other by cash flows and, of course, each having impact on bank stability.

It is important to note, though that the number of criteria chosen must not exceed, say fifteen criteria to make the task feasible for experts involved.

Each criterion is either maximising or minimising, i.e. the best value of the maximising criterion is achieved at its maximum value. Conversely, the best value of the minimising criterion is achieved at its minimum value. A minimising criterion can be inversed to the maximising one by attaching the negative sign. At the second stage, a group of experts is allocating weights to each criterion, sum of weights of each expert making the one, or in other terms $100 \%$ (Ginevičius 2006, 2008). Experts can only provide quite subjective opinions, so at the third stage their opinions, which are expressed in sets of allocated weights are compared among themselves and their statistical compatibility is derived from data collected. Such compatibility is expressed by Kendall's coefficient of concordance, which shows the level of similarity of perception of criteria by experts (Kendall 1955; Podvezko 2007). Of course, their opinions can be contradicting and this will make Kendall's co-efficient close to zero. At the fourth stage statistical data is gathered up or in case it is not available, experts provide their expressions of such data. Again, in the latter case Kendall's coefficient is calculated in order to find out if experts' opinions are compatible. At the fifth stage a multi-criteria method is chosen and applied using the set of criteria obtained at the stage one, weights obtained at the stage two and data obtained at the stage four (SAW, TOPSIS, COPRAS). In case more complex methods are chosen (PROMETHEE, ELECTRE) types of preference functions or their analogues and their parameters are set again by experts at the sixth stage (Podvezko, Podviezko 2010). At the final seventh stage data are evaluated and conclusions are made, in most cases in the form of outranking table with sorted alternatives in the order of preference.

In order to obtain bank evaluation using described above multi-criteria, such criteria must be outlined and approved. The set of criteria must serve to a certain goal. The choice of criteria will determine the ranking outcome. International bank rating industry is representing interests of either investors' or the government. The latter case is best represented by the CAMELS rating frame, the 
most known example when ratings are directly used by regulators. The frame has been worked out by the FDIC, the Federal Reserve and the OCC (Lopez 1999) and for quite a long time already applied as a preventive measure in the U.S.A.

Bank evaluation draws interest also from other perspective than of investors', regulators' or governments'. For example, Lithuanian banks were evaluated from client perspective (Ginevičius, Podvezko 2008a) and by their impact to the local economy according to values of their performance indices (Dudzeviciūte 2006). The choice of criteria strongly depends on the aim of the analysis. We are focusing, unlike most of rating agencies on evaluation of banks from depositor's perspective, both individual and corporate. Therefore, unlike say Moody's Investors Service Inc. agency's strategy to put emphasise on the qualitative analysis, we focus on quantitative analysis using widely available financial data from annual reports of banks. For evaluation of bank stability, a set of criteria must be chosen. Obtained values of criteria within this set will determine the outcome of the evaluation.

\section{Approach of evaluation}

Being determined to evaluate stability of banks from depositors' perspective, we are focusing on the local market of Lithuania, which is by the definition of Moody's Investors Service Inc. is presently falling to the developing market category. In fact, foreign and local currency ratings of the government of Lithuania were never reaching the threshold of Aal set by Moody's Investors Service Inc. (Fanger 2007). Moreover, the rating was recently downgraded by Moody's Investors Service Inc. from A2 to A3 on 23 April, 2009 with the negative outlook. We are focusing on the banks, which are operating in the same local economic environment by eliminating foreign banks, which have only branches in Lithuania and are not registered as enterprises in this country. We make thus the analysis fairer, since banks we are evaluating are in general terms operating in the same economic environment, which gives neither a credit nor downgrades a bank because of advantages or disadvantages of the environment, where the bank is registered. Among major eleven banks there are three foreign banks present in the local market, which operate in Lithuania only as branches (not as affiliates registered in Lithuania as applies to other banks of foreign capital), namely Nordea Bank Finland Plc, A/S "Unicredit Bank" and Danske Bank A/S, and these are the banks we will have to exclude from evaluation as they are only branches of banks operating in different environment. Evaluated banks therefore are the following local banks (listed in the alphabetical order):
1. AB DnB NORD
5. AB Šiaulių Bankas
2. UAB Medicinos Bankas
3. AB Parex Bankas
6. AB bankas SNORAS
7. AB Swedbank
4. AB SEB Bankas
8. AB Ūkio Bankas.

Again, by such narrowing research to exclusively local banks we eliminate adjustments of ratings made by international credit agencies in regard to the status of the local market accordingly of being mature or developing, as they often mention in their rating methodologies (e.g. Fanger 2007). Such an adjustment is intended for large investors acting in the global environment, which are main consumers of major rating agencies products. Conversely, local depositors in foreign currencies usually do not have much choice. They can either consider only local banks to allocate deposits in foreign currency or only branches of foreign banks with higher international ratings as all foreign banks acting as branches usually do not compete in terms of interest rates offered for deposits in the most popular foreign currency the euro (Table 1).

Table 1. Interest Rates for Term Deposits in EUR for the Term of One Year, as of Beginning of 2010

\begin{tabular}{|c|l|c|}
\hline No. & \multicolumn{1}{|c|}{$\begin{array}{c}\text { Offers of branches of foreign } \\
\text { banks }\end{array}$} & $\begin{array}{c}\%, \quad \text { per } \\
\text { annum }\end{array}$ \\
\hline 1. & Danske Bank A/S & $0.8 \%$ \\
\hline 2. & Nordea Bank Finland Plc & $0.8 \%$ \\
\hline 3. & A/S “Unicredit Bank” & $1.3 \%$ \\
\hline No. & Offers of local banks & \\
\hline 1. & AB DnB NORD & $0.9 \%$ \\
\hline 2. & UAB Medicinos Bankas & $3.75 \%$ \\
\hline 3. & AB Parex Bankas & $4 \%$ \\
\hline 4. & AB SEB Bankas & $0.6 \%$ \\
\hline 5. & AB Šiaulių Bankas & $3.4 \%$ \\
\hline 6. & AB bankas SNORAS & $3.5 \%$ \\
\hline 7. & AB Swedbank & $0.7 \%$ \\
\hline 8. & AB Ūkio Bankas & $3.7 \%$ \\
\hline
\end{tabular}

So, while rating agencies are strenuously distinguishing sovereign ceilings of countries thus placing banks with similar financial track record to divergent ranks whenever they are operating in countries with different foreign currency ceilings, we intend to evaluate banks working in the same environment, the local market and we believe that the outranking outcome on local bank stability can thus provide an unambiguous picture especially in the circumstances, when foreign and local currency ratings of the government of Lithuania were recently downgraded.

Considering the span of concern of depositors, it obviously differs from the one of investor. Major 
rating agencies are representing interests of large investors and Moody's Investors Service Inc., for example clearly states that it is focusing primarily on the Long-Term perspective. This is clearly outlined in their succinct rating approach called "A "Universal" Approach to Credit Analysis". A depositor, by the other hand is primarily interested in the short-term stability of a bank. In fact, terms of most of term deposits in Lithuania $(97.8 \%$ as of end of November, 2009) are of the term up to one year (The Bank of Lithuania 2009/11), so is the span of concern of depositors.

Another difference between concern of a depositor and of a rating agency is in the focus of the latter in the qualitative approach as span of evaluation of the latter is rather long, usually even longer than length of business cycle (see the rating approach mentioned above). We will intend to use quantitative criteria, since span of our concern is shorter and uniform numerical approach based on widely available annual financial data could yield an objective outcome for all banks being evaluated. This approach is in line with the newly adopted approach of Fitch Ratings Ltd. agency, which has developed a universal spreadsheet for bank analysis (Lee et al. 2009).

It is observed that major rating agencies as Fitch Ratings Ltd., AM Best and Moody's Investors Service Inc. use already widely known traditional economic ratios for their bank evaluation spreadsheets.

Table 2. Debt Ratings of Eight Rating Agencies (Cantor, Packer 1994)

\begin{tabular}{|c|c|c|c|}
\hline Agency & $\begin{array}{c}\text { Number } \\
\text { jointly } \\
\text { rated }\end{array}$ & $\%$ split & Correlation \\
\hline S\&P & 351 & 63 & 0.77 \\
\hline CBRS & 11 & 91 & 0.52 \\
\hline DBRS & 17 & 71 & 0.61 \\
\hline Duff & 139 & 58 & 0.84 \\
\hline Fitch & 68 & 62 & 0.77 \\
\hline IBCA & 206 & 89 & 0.88 \\
\hline JBRI & 19 & 100 & 0.73 \\
\hline NIS & 351 & 63 & 0.81 \\
\hline
\end{tabular}

To conclude the idea of necessity of additional research on bank soundness and stability let us recall the outcome of the research carried out in 1994 by Cantor and Packer, which revealed a far from perfect correlation starting from as low as 0.52 between bank ratings of seven rating agencies compared to Moody's Investors Service Inc. (Standard and Poor's Rating Services, Moody's Investors Service Inc., Fitch Ratings Ltd., IBCA, A. M. Best
Company, DBRS Ltd. (Dominikon Bond Rating Service), Japan Credit Rating Agency, Ltd., Rating and Investment Information, Inc., CBRS (Canadian Bond Rating Service), Duff (Duff and Phelps Credit Rating Service), JBRI (Japanese Bond Rating Institute), NIS (Nippon Investor Service)) (Cantor, Packer 1994; Morgan 1997).

\section{Quantitative criteria for evaluation of bank stability}

The CAMELS approach used by bank supervisors in the U.S.A. for evaluations of banks by the six letters roughly describes core points of analysis framework used by major rating agencies. This acronym represents six conditions of stable and sound bank performance, described as follows.

'C' Capital adequacy.

' $A$ ' Asset quality is the ratio of non-performing loans to total loans.

'M' Management quality, cost control, emphasis on types of business activities.

'E' Earnings. Under this item such ratios are looked into as earnings to assets and to equity.

'L' Liquidity. This item usually comprises such ratios as liquidity ratio, loans-to-assets, deposits-toassets, etc.

'S' Sensitivity to market risk reflects the degree to which changes in interest rates, foreign exchange rates, commodity prices, or equity prices can adversely affect a financial institution's earnings or economic capital.

As an example, 52 major Indonesian banks were evaluated using CAMEL variables (without the last 'Sensitivity' variable as it was not adopted in that country) using multiple linear regression model with bank-specific and other error correction (Garbarro et al. 2002). Authors found out that in crisis all CAMEL variables deteriorate with the exception of Earnings" variable, which remained stable.

Unfortunately, the CAMELS methodology and exam ratings of banks are not publicly disclosed as opposed to methodologies of rating agencies, most of which explicitly describe both quantitative chart and qualitative analysis framework (Curry et al. 2007, De Young et al. 1998).

As we focus on the quantitative analysis, let us consider the part of the scorecard used by Moody's Investors Service Inc. representing quantitative part of analysis and the spreadsheet used by Fitch Ratings Ltd.

The scorecard outlined in Table 3 was slightly transformed in order to fit our needs.

Table 3. Bank Financial Strength Ratings Scorecard Weights (Adopted from Fanger 2007). 


\begin{tabular}{|c|c|c|c|c|c|}
\hline & Factor & $\begin{array}{l}\text { Category } \\
\text { Weight }\end{array}$ & Sub-Factor & $\begin{array}{l}\text { Sub- } \\
\text { Factor } \\
\text { Weight }\end{array}$ & $\begin{array}{l}\text { Concluding } \\
\text { Weight }\end{array}$ \\
\hline \multirow{10}{*}{ 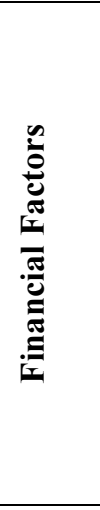 } & \multirow[t]{2}{*}{ Profitability } & \multirow[t]{2}{*}{$15.75 \%$} & PPP \% Avg RWA & $50 \%$ & $7.875 \%$ \\
\hline & & & Net Income \% Avg RWA & $50 \%$ & $7.875 \%$ \\
\hline & \multirow[t]{2}{*}{ Liquidity } & \multirow[t]{2}{*}{$15.75 \%$} & (Market funds - Liquid Assets) \% Total Assets & $44 \%$ & $6,93 \%$ \\
\hline & & & Liquidity Management & $56 \%$ & $8.82 \%$ \\
\hline & \multirow{2}{*}{$\begin{array}{l}\text { Capital } \\
\text { Adequacy }\end{array}$} & \multirow[t]{2}{*}{$15.75 \%$} & Tier 1 ratio $(\%)$ & $50 \%$ & $7.875 \%$ \\
\hline & & & Tangible Common Equity \% RWA & $50 \%$ & $7.875 \%$ \\
\hline & Efficiency & $7 \%$ & Cost/income ratio & $100 \%$ & $7.00 \%$ \\
\hline & \multirow{2}{*}{$\begin{array}{l}\text { Asset Qual- } \\
\text { ity }\end{array}$} & \multirow[t]{2}{*}{$15.75 \%$} & Problem Loans \% Gross Loans & $50 \%$ & $7.875 \%$ \\
\hline & & & Problem Loans \% (Equity + LLR) & $50 \%$ & $7.875 \%$ \\
\hline & $\begin{array}{l}\text { Lowest } \\
\text { Score }\end{array}$ & $30 \%$ & $\begin{array}{l}\text { Assigned to lowest combined financial } \\
\text { factor score }\end{array}$ & $100 \%$ & $30.00 \%$ \\
\hline $\begin{aligned} \text { PPP } \\
\text { RWA }\end{aligned}$ & \multicolumn{5}{|c|}{$\begin{array}{l}\text { Pre-Provision Profits } \\
\text { Average Risk-Weiohted Assets }\end{array}$} \\
\hline
\end{tabular}

Table 4. The Standardized Spreadsheet Used by Fitch Ratings Ltd. (adopted from Lee, Rawcliffe et al. 2009)

\begin{tabular}{|c|c|}
\hline $\begin{array}{l}\text { Interest Ratios } \\
\text { Interest Income on Loans/Average Gross Loans } \\
\text { Interest Expense on Customer Deposits/Average Customer Deposits } \\
\text { Interest Income/Average Earning Assets } \\
\text { Interest Expense/Average Interest-Bearing Liabilities } \\
\text { Net Interest Income/Average Earning Assets } \\
\text { Net Interest Income Less Loan Impairment Charges/Average Earn- } \\
\text { ing Assets }\end{array}$ & $\begin{array}{l}\text { Funding } \\
\text { Loans/Customer Deposits } \\
\text { Interbank Assets/Interbank Liabilities }\end{array}$ \\
\hline $\begin{array}{l}\text { Other Operating Profitability Ratios } \\
\text { Non-Interest Income/Gross Revenues } \\
\text { Non-Interest Expense/Gross Revenues } \\
\text { Non-Interest Expense/Average Assets } \\
\text { Pre-Impairment Operating Profit/Average Equity } \\
\text { Pre-Impairment Operating Profit/Average Total Assets } \\
\text { Loans and Securities Impairment Charges/Pre-Impairment Operating } \\
\text { Profit } \\
\text { Operating Profit/Average Equity Operating Profit/Average Total } \\
\text { Assets } \\
\text { Taxes/Pretax Profit }\end{array}$ & $\begin{array}{l}\text { Other Profitability Ratios } \\
\text { Net Income/Average Total Equity } \\
\text { Net Income/Average Total Assets } \\
\text { Fitch Comprehensive Income/Average Total } \\
\text { Equity } \\
\text { Fitch Comprehensive Income/Average Total } \\
\text { Assets } \\
\text { Net Income/Average Total Assets plus Av- } \\
\text { erage Managed Assets }\end{array}$ \\
\hline $\begin{array}{l}\text { Capitalization } \\
\text { Core Capital/Regulatory Weighted Risks } \\
\text { Fitch Eligible Capital/Regulatory Weighted Risks } \\
\text { Tangible Common Equity/Tangible Assets } \\
\text { Tangible Common Equity/Total Business Volume } \\
\text { Tier 1 Regulatory Capital Ratio } \\
\text { Total Regulatory Capital Ratio } \\
\text { Fitch Eligible Capital/Tier 1 Regulatory Capital } \\
\text { Equity/Total Assets } \\
\text { Cash Dividends Paid and Declared/Net Income } \\
\text { Cash Dividend Paid and Declared/Fitch Comprehensive Income } \\
\text { Net Income - Cash Dividends/Total Equity }\end{array}$ & $\begin{array}{l}\text { Loan Quality } \\
\text { Growth of Total Assets } \\
\text { Growth of Gross Loans } \\
\text { Impaired Loans(NPLs)/Gross Loans } \\
\text { Reserves for Impaired Loans/Impaired } \\
\text { Loans } \\
\text { Impaired Loans Less Reserves for Impaired } \\
\text { Loans/Equity } \\
\text { Loan Impairment Charges/Average Gross } \\
\text { Loans } \\
\text { Net Chargeoffs/Average Gross Loans } \\
\text { Impaired Loans + Foreclosed Assets/Gross } \\
\text { Loans + Foreclosed Assets }\end{array}$ \\
\hline
\end{tabular}

Only financial part was taken, omitting the qualitative part and weights adjusted accordingly. The standardized spreadsheet used by Fitch Ratings Ltd. is as follows (Table 4). In the charts of both rating agencies we note all elements of
CAMEL framework with the exception of 'Management' variable, which is qualitative and is not included in the scope of our analysis.

As was already mentioned, choice of criteria must be restricted to no more than around a dozen 
to make it possible to experts to comprise the criteria and allocate weights, choose types of preference functions (for the PROMETHEE method) and their parameters (Podvezko, Podviezko 2009a, 2009b). Such a number well corresponds to politics of Fitch Ratings Ltd., which uses 3-6 qualitative factors (Metz, Costello 2009; Beck et al. 2005; Cates et al. 2009) and A.M. Best Co. (Vuong 2005, 2007). Broad and suitable table of criteria is outlined in methodology by Moody's Investors Service Inc. (Fanger 2007), which we intend to use as a base as it has an acceptable number of criteria. The last "Lowest Score" criterion draws a comment though. It was incorporated to the chart for the purpose of adding a $30 \%$ additional weight to the lowest score within the following four categories: Asset Quality, Liquidity, Capital Adequacy, or the combined Profitability/ Efficiency. The last category Profitability/ Efficiency is a combined weighted average value of both Efficiency category and Profitability category. It is determined before the extra weighting is applied. Profitability and Efficiency are combined to one category in order to reduce the impact which a low score on Efficiency alone would have on the overall scorecard estimate.

Methodology proposed by Moody's Investors Service Inc. relinquishes scoring weights in favour of the criterion of the worst score with substantial additional prominence of $30 \%$ to it. Such weight augmentation raises a number of questions. First, we note that prominence is granted to only one criterion of the worst outcome leaving the next criterion to it unnoticed, even if the difference between values could be small. Next, such weight prominence is attached to the criterion listed on the left-hand side of the Table 3 (factor) instead of distinguishing values of components outlined in the right-hand side of the table (sub-factors). Nevertheless, the idea of relinquishing the scoring in favour of the worst scores thus emphasising them will be used in computational model by choosing such preference functions, which would reckon all worst scores as having stronger impact on the general evaluation outcome.

Let us separately observe importance of each criterion (factor), which is going to be used in quantitative evaluation.

Profitability is of extreme importance to a bank. Whenever profitability is stable, it could be used to cover losses in worse performing areas of business. Profits are measured against riskweighted assets as measured under the Basel I rules as a potential possibility for coverage for creditors. Using risk-weighted assets instead of their book value comprises risk in both balance sheet and off-balance sheet.

The first sub-factor in the Profitability section is profits before provisions and taxes compared to risk-weighted assets. It shows the ability of the bank to cover its losses in other areas of business.

The second sub-factor in this section netincome compared to risk-weighted assets shows the ability of the bank to remain profitable after covering of all its expenditures.

Liquidity. A bank cannot function without liquidity. Breach of certain level of liquidity is the major cause of failure of banks. In case if illiquid assets of a bank are financed with its core liabilities as equity, customer deposits and long-term loans, then the bank does not face liquidity severity at the time when signs of a negative perception of a bank appear in the market. Usually, risk of withdrawal of market funds as interbank loans, bank bonds, commercial papers, and derivatives is high at the time and such a probable risk is unacceptable to cause liquidity problems. (Bauer et al. 2003, Fanger 2007))

The first sub-factor is showing the rate of dependence of the bank on external financing rather than its core liabilities. It is clearly a minimising factor.

The second sub-factor is qualitative and we propose to use as a criterion comparison of liquidity index of a bank with $30 \%$ imposed by The Bank of Lithuania for our quantitative research instead.

Capital Adequacy. The first sub-factor (Tier 1 ratio to risk-weighted assets) is more prudent than the regulatory one as the latter accounts Tier 2 and Tier 3 capital. It is easy to adjust the ratio though using data from annual reports.

The second sub-factor (tangible common equity to risk-weighted assets) is also easy to derive from local accounting statements. Intangible assets in Lithuanian banks make up less than one percent of total assets; preferred equity was accounted only in statements of AB bankas SNORAS.

Risk-weighted assets are well disclosed in financial statements of local banks.

Efficiency ratio compares total non-interest expense with total revenues and it shows the ability to create additional value compared to operating expense.

Asset Quality. Problem loans volume is impaired loans as is defined in paragraph 39 of International Accounting Standard, which is adopted in Lithuania from 1 July, 2008 (IASB 2009). This means that banks are required to disclose related data starting from annual report for 2009. 
The second sub-factor compares total impaired loans with equity together with loan loss reserves.

\section{Additional Criteria}

Other criteria that did not fall to CAMEL framework may well add insight over evaluated banks.

\section{Client Criteria:}

Interest rates offered to depositors is the criterion as important as all other ones disclosing bank riskiness. This criterion is the first a depositor is exposed to upon his/her decision to make a deposit with a bank. It should be properly weighted to balance riskiness of banks.

Distance to the location of a bank may also outweigh some other criteria dependent on which weight a client allocates to this criterion.

Availability of options in the deposit agreement as early withdrawal, free cash withdrawal, automatic renewal with additional grace interest surplus, internet monitoring and steering of deposits, length of period after which free withdrawal is granted.

Fringe benefits offered upon signing a deposit agreement (free insurance, discount cards, beneficial memberships, sweepstakes, upgrade of client status, etc).

\section{Market risk:}

Variance of the ratio interest revenue to noninterest revenue over the business cycle period is disclosing quality of management of market risk.

\section{Economic Insolvency:}

Insufficient Charge off to Loan Portfolio by certain banks has become an issue of speculations in this country. Such criterion as increase of the ratio of total loans to total assets signals reluctance of management of the bank to write off impaired loans meaning growth of the book value of loan portfolio. This criterion is intended to downgrade banks, which insufficiently write off impaired loans and outweigh loss of profitability of other banks in favour of improving bank loan portfolio.

Economic Insolvency Override criterion is defined by Moody's Investors Service Inc. as follows:

$(1-(0.5 \times$ PL / (Equity + LLR $))) \times$ Tier 1

where PL is problem loans, LLR loan loss reserves. It downgrades a bank, when this ratio falls below $4 \%$ (Fanger 2007).

\section{Conclusions}

Problem of evaluation of local banks from depositor's perspective was laid. Its distinctiveness from prevailing approaches was shown. Methods of ma- jor rating agencies were analysed, mismatch of approaches of the agencies and goals of our research were identified and outlined.

Major criteria for bank multi-criteria evaluation were described, which is a necessary important groundwork for evaluation of banks. Importance of such criteria to our research was revealed.

New criteria for evaluation of local banks were proposed.

A methodology for multi-criteria evaluation of local banks from depositor's perspective was proposed. Several multi-criteria evaluation methods were suggested for such evaluation: SAW, TOPSIS, COPRAS, PROMETHEE.

\section{References}

Bauer, G. W. et al. 2003. Bank Liquidity Risk and Short-Term Bank Deposit Ratings. Moody's Investors Service Inc. [online]. Available from Internet: $<$ www.moodys.com $>$.

Beck, T.; Ramadurai, K.; Linnell, J.; Andrews, D.; Cartmell, B.; Yimaz, E.; Marshall, D.; Spring, D. 2005. Bank Operational Risk Assessment Methodology. New York: Fitch Ratings Ltd. [online]. Available from Internet: < $w w w$.fitchratings.com $>$.

Cantor, R.; Packer, F. 1994. The Credit Rating Industry, Federal Reserve Bank of New York Quarterly Review 12: 1-26

Cates, J., Gandy, B.; Hoffmann, D.; Shaw, P.; Steinbarth, M.; Tebbutt, P. 2009. A Universal Spreadsheet for Bank Analysis. New York: Fitch Ratings Ltd. [online]. Available from Internet: $<$ www.fitchratings.com>.

Curry, T. J.; Fissel, G. S.; Hanweck, G. A. 2007. Is There Cyclical Bias in Bank Holding Company Risk Ratings? FDIC Center for Financial Research Working Paper 3: 1-40.

Dudzeviciūtè, G. 2006. The Impact of a Banking Sector on Economic Growth: Theoretical and Practical Aspects, Verslas: teorija ir praktika [Business: Theory and Practice] 7(2): 128-135.

Fanger, D. 2007. Bank Financial Strength Ratings: Global Methodology. Moody's Investors Service [online]. Available from Internet:

$<$ www.moodys.com>.

FDIC. 2010a. Failed Bank List [online]. Available from Internet:

$<$ www.fdic.gov/bank/individual/failed/banklist.html $>$.

FDIC. 2010b. Deposit Insurance Simplification Fact Sheet [online] Available from Internet: $<$ http://www.fdic.gov/deposit/deposits/dis/print/dis english.pdf $>$.

Figueira, J.; Greco, S.; Ehrgott, M. 2005. Multiple Criteria Decision Analysis: State of the Art Survey. New York: Springer.

Foley, T. et al. 2007. Request for Commitment: RiskBased Framework for Assessing the Capital Adequacy of Financial Institutions. New York: Stan- 
dard\&Poors [online]. Available from Internet: $<$ www.standardandpoors.com $>$.

Gasbarro, D.; Sadguna, I. G. M.; Zumwalt, J. K. 2002. The Changing Relationship Between CAMEL Ratings and Bank Soundness during the Indonesian Banking Crisis, Review of Quantitative Finance and Accounting 19: 247-260. doi:10.1023/A:1020724907031

Ginevičius, R.; Podvezko, V. 2004. Assessing the Accuracy of Expert Methods, Inzinerine Ekonomika Engineering Economics 5(40): 7-12.

Ginevičius, R. 2006. Multicriteria Evaluation of the Criteria Weights Based on their Interrelationship, Verslas: teorija ir praktika [Business: Theory and Practice] 7(1): 3-13.

Ginevičius, R.; Podvezko, V. 2008a. Multicriteria Evaluation of Lithuanian Banks from the Perspective of their Reliability for Clients, Journal of Business Economics and Management 9(4) 257-267. doi:10.3846/1611-1699.2008.9.257-267

Ginevičius, R.; Podvezko, V. 2008b. Daugiakriteriniu vertinimo būdų suderinamumas [The Problem of Compatibility of Various Multiple Criteria Evaluation Methods], Verslas: teorija ir praktika [Business: Theory and Practice] 9(1): 73-80. doi:10.3846/1648-0627.2008.9.73-80

Ginevičius, R.; Podvezko, V. 2008c. Daugiakriterinio vertinimo taikymo galimybès kiekybiniam socialinių reiškinių vertinimui [A Feasibility Study of Multicriteria Methods' Application to Quantitative Evaluation of Social Phenomena], Verslas: teorija ir praktika [Business: Theory and Practice] 9(2): 81-87. doi:10.3846/1648-0627.2008.9.81-87

Ginevičius, R. 2008. Normalization of Quantities of Various Dimensions, Journal of Business Economics and Management 9(1): 79-86. doi:10.3846/1611-1699.2008.9.79-86

IASB. 2009. International Accounting Standard 39. International Accounting Standard Board (IASB) [online]. Available from Internet: $<$ www.iasb.org $>$.

Indèliu draudimas [Deposit Insurance]. 2010 [online] Available from Internet:

$<$ http://www.iidraudimas.lt/lt/indeliu-draudimas $>$.

Jonaitis, V.; Kriaučiūnaitè, J., Griesiūtè, M. 2003. Bankų kreditų naudojimas būsto sąlygoms gerinti [The use of Crediting Sources for the Improvement of Housing Conditions], Technological and Economic Development of Economy 9(1) 34-38.

Kendall, M. 1955. Rank Correlation Methods. New York: Hafner Publishing House.

Le Bras, A.; Andrews, D. 2004. Bank Ratig Methodology. New York: Fitch Ratings Ltd. [online]. Available from Internet: $<$ www.fitchratings.com $>$.

Lee, J. Y.; Rawcliffe, G.; Abruzzo, T.; Moss, J.; Marshall, D.; Peach, J.; Shaw, P. 2009. Global Financial Institutions Rating Criteria. New York: Fitch Ratings Ltd. [online]. Available from Internet: $<$ www.fitchratings.com $>$.

Lopez, J. A. 1999. Using CAMELS Ratings to Monitor Bank Conditions, Working Papers of Federal Re- serve Bank of San Francisco Economic Letter 99(19): $1-4$.

Metz, M. G.; Costello, G. 2009. Guidelines for Developing and Revising Criteria. New York: Fitch Ratings Ltd. [online]. Available from Internet: $<$ www.fitchratings.com $>$.

The Bank of Lithuania. 2009. Monthly Bulletin 2009/11. Vilnius: The Bank of Lithuania [online]. Available from Internet: $<$ www.lb.lt $>$.

The Banker. 2009. Top 500 Banking Brands [online]. Available from Internet: <www.thebanker.com>.

Morgan, D. P. 1997. Judging the Risk of Banks: What Makes Banks Opaque? Working Papers of Federal Reserve Bank of New York 98(5): 1-29. doi:10.2139/ssrn.159754

Podvezko, V. 2006. Neapibrezžtumo ịtaka daugiakriteriniams vertinimams [Multicriteria evaluation under uncertainty], Verslas: teorija ir praktika [Business: Theory and Practice] 7(2): 81-88

Podvezko, V. 2007. Determining the level of agreement of expert estimates, International Journal of Management and Decision Making 8(5/6): 586-600. doi:10.1504/IJMDM.2007.013420

Podvezko, V. 2008. Sudètingų dydžių kompleksinis vertinimas [Comprehensive Evaluation of Complex Quantities], Verslas: teorija ir praktika [Business: Theory and Practice] 9(3): 160-168. doi:10.3846/1648-0627.2008.9.160-168

Podvezko, V.; Podviezko, A. 2009a. Prioritetų funkciju itaka daugiakriterimiams vertinimams [Influence of Preference Functions to Multi-Criteria Evaluation Outcome], Lietuvos matematikos rinkinys. LMD darbai [Collection of Papers by Members of Lithuanian Mathematical Society] 50: 209-211

Podvezko, V.; Podviezko, A. 2009b. PROMETHEE I metodo naudojimas, nustatant geriausią alternatyvą [PROMETHEE I Method Application for Identification of the Best Alternative], Verslas: teorija ir praktika [Business: Theory and Practice] 10(2):8492. doi:10.3846/1648-0627.2009.10.84-92

Podvezko, V.; Podviezko, A. Dependence of Multicriteria Evaluation Result on Choice of Preference Functions and Their Parameters, Technological and Economic Development of Economy 16(1): 143158. doi:10.3846/tede.2010.09

Shedlock, M. 2009. FDIC Depositor Insurance Scheme is Bankrupt! The Market Oracle [online]. Available from Internet:

$<$ http://www.marketoracle.co.uk/Article12767.html $>$.

Vuong, K. 2005. Analyzing Commercial Banking Operations. Oldwick: A.M. Best Company, Inc. [online]. Available from Internet: $<$ www.ambest.com>.

Vuong, K. 2007. Rating Methodology for Banks. Oldwick: A. M. Best Company, Inc. [online]. Available from Internet: <www.ambest.com $>$. 